\title{
Wood density provides new opportunities for reconstructing past temperature variability from southeastern Australian trees
}

\section{Authors}

Alison J. O'Donnell ${ }^{1 *}$, Kathryn J. Allen ${ }^{2}$, Robert M. Evans ${ }^{2}$, Edward R. Cook ${ }^{3}$, Valerie Trouet ${ }^{4}$, Patrick J. Baker $^{2}$

\section{Author Affiliations}

${ }^{1}$ School of Plant Biology, University of Western Australia, Crawley, Western Australia, 6009, Australia

${ }^{2}$ School of Ecosystem and Forest Sciences, University of Melbourne, Richmond, Victoria, 3121, Australia

${ }^{3}$ Tree Ring Laboratory, Lamont-Doherty Earth Observatory, Palisades, New York, 10964, USA

${ }^{4}$ The Laboratory of Tree-Ring Research, University of Arizona, Tucson, Arizona, 85721, USA

*Corresponding author: Alison O'Donnell

School of Plant Biology M090,

University of Western Australia,

35 Stirling Highway,

Crawley, Western Australia, 6009.

Email: alison.odonnell@uwa.edu.au

Keywords: cell wall thickness, SilviScan, Tasmania, tree-ring width, Southern Annular Mode, subtropical ridge 


\section{Abstract}

2 Tree-ring based climate reconstructions have been critical for understanding past variability and

3 recent trends in climate worldwide, but they are scarce in Australia. This is particularly the case for

4 temperature: only one tree-ring width based temperature reconstruction - based on Huon Pine

5 trees from Mt Read, Tasmania - exists for Australia. Here, we investigate whether additional treering parameters derived from Athrotaxis cupressoides trees growing in the same region have potential to provide robust proxy records of past temperature variability.

8 We measured wood properties, including tree-ring width (TRW), mean density, mean cell wall

9 thickness (CWT), and tracheid radial diameter (TRD) of annual growth rings in Athrotaxis

10 cupressoides, a long-lived, high-elevation conifer in central Tasmania, Australia. Mean density and

11 CWT were strongly and negatively correlated with summer temperatures. In contrast, the summer temperature signal in TRW was weakly positive. The strongest climate signal in any of the tree-ring parameters was maximum temperature in January (mid-summer; JanT $T_{\max }$ ) and we chose this as the target climate variable for reconstruction. The model that explained most of the variance in JanT $T_{\max }$ was based on TRW and mean density as predictors. TRW and mean density provided complementary proxies with mean density showing greater high-frequency (inter-annual to multi-year) variability and TRW showing more low-frequency (decadal to centennial-scale) variability. The final reconstruction model is robust, explaining $55 \%$ of the variance in JanT $\mathrm{Tax}_{\max }$ and was used to reconstruct JanT $T_{\max }$ for the last five centuries (1530-2010 C.E.). The reconstruction suggests that the most recent 60 years have been warmer than average in the context of the last ca. 500 years. This unusually warm period is likely linked to a coincident increase in the intensity of the subtropical ridge and dominance of the positive phase of the Southern Annular Mode in summer, which weaken the influence of the band of prevailing westerly winds and storms on Tasmanian climate. Our findings indicate that wood properties, such as mean density, are likely to provide significant 
contributions toward the development of robust climate reconstructions in the Southern

Hemisphere and thus toward an improved understanding of past climate in Australasia.

27

\subsection{Introduction}

Tree-ring based reconstructions of climate have been critical for understanding past climate variability and placing recent climatic trends in a long-term context. However, for most of the Southern Hemisphere, including Australia, there are few tree-ring based climate reconstructions, which constrains our understanding of recent and potential future climatic changes. In Australia, the limited number of tree-ring based climate reconstructions is largely attributable to a lack of tree species that are suitable for dendrochronology. The dominant angiosperm genera do not generally produce visually distinct or strictly annual rings suitable for dendrochronological methods (Schweingruber, 1992), but recent progress points to the potential some of these genera may hold (Brookhouse and Brack, 2006; Brookhouse et al., 2008; Heinrich et al., 2009; Whinder et al., 2013). In addition to this, the primary focus of Australian dendrochronology has been on tree-ring width (TRW) - the most commonly used tree-ring parameter in chronology development globally - which has failed to provide clear climatic signals in many of the species and sites examined to date. Recent successes in the reconstruction of past rainfall and/or drought indices have used TRW measurements from the mainland conifer Callitris columellaris (including the previously named $C$. intratropica, Farjon, 2005) in the north and west of the continent (Cullen and Grierson, 2009; D’Arrigo et al., 2008; O’Donnell et al., 2015). However, to date, the only temperature reconstruction derived from TRW is based on Huon Pine (Lagarostrobos franklinii) from one high-elevation site (Mount Read, 900 m.a.s.l) in Tasmania (Cook et al. 1991; Cook et al. 1992; Cook et al. 2000). Globally, this is also one of the longest tree-ring based climate reconstructions (1600 B.C.E.-1991 C.E.). Despite considerable efforts over the past two decades, high-quality reconstructions of temperature based on low-elevation Huon Pine TRW (Buckley et al., 1997) and TRW of other long- 
Other physical wood properties (i.e., density, cell wall thickness (CWT), tracheid radial diameter (TRD), and microfibril angle (MFA); e.g., Drew et al., 2013) as well as chemical wood properties (i.e., stable isotope concentrations, e.g., Treydte et al. 2006; Brienen et al. 2012, and trace element concentrations, e.g., Poussart et al., 2006) are also known to record climatic information. In particular, strong temperature signals have been identified in the wood density of conifers across Europe (e.g., Briffa et al., 2002; Büntgen et al., 2010; Trouet, 2014) and North America (e.g., Briffa et al., 1992; D’Arrigo et al., 1992; Davi et al., 2003; Luckman and Wilson, 2005; Wilson et al., 2007). In many cases, wood density, particularly maximum latewood density (MXD), has been more strongly correlated with temperature and over a longer summer season than TRW (Briffa et al., 2002; Grudd, 2008; Tuovinen et al., 2009; Trouet et al., 2012). Consequently, MXD has been widely used in the Northern Hemisphere to build temperature-sensitive chronologies (e.g., Schweingruber and Briffa, 1996; Frank and Esper, 2005; Grudd, 2008) and to reconstruct summer temperatures over the last several centuries to millennia (e.g., Briffa et al., 1992; Luckman and Wilson, 2005). Recent work has also demonstrated the potential of various wood properties (e.g., CWT, TRD, MFA, and mean ring density) of several long-lived Tasmanian conifers as sources of past climatic information (Allen et al., 2012; Drew et al., 2013; Allen et al., 2013) and for reconstructing stream flow (Allen et al., 2015). Despite this potential, temperature reconstructions based on these wood properties have not yet been developed.

Here, we investigate the potential of several of these wood properties for reconstructing past temperatures in Australia. We focus on the native conifer, Athrotaxis cupressoides (Pencil Pine), which is endemic to high-elevation (700-1300 m.a.s.I) areas of Tasmania (Farjon, 2005). In addition to TRW, we measured mean density, TRD, and CWT. Given the strength of climatic signals previously identified in these wood properties, we expect that chronologies based on wood properties, 
particularly mean density, will allow us to produce the first robust $A$. cupressoides-based temperature reconstruction in Tasmania.

\section{Methods}

\subsection{Site description}

We collected $A$. cupressoides samples at two high elevation sites ( 1200 m.a.s.l) in central Tasmania, Australia $\left(41.742^{\circ} \mathrm{S}, 146.703^{\circ} \mathrm{E}\right.$; Fig. 1a). The first site is adjacent to Pine Lake. The other site is on a southwest-facing slope adjacent to Mickey Creek. These two sites are ca. $1.5-2 \mathrm{~km}$ apart on Tasmania's Central Plateau. The Pine Lake-Mickey Creek (PLMC) site is approximately $100 \mathrm{~km}$ east of the Mt Read site ( 900 m.a.s.I.) that was sampled to develop the only existing tree-ring based temperature reconstruction in Australia (Cook et al. 1991; Cook et al. 1992; Cook et al. 2000). Climate at the PLMC site is characterised by cold and wet conditions in the winter and spring months (May-Oct) and comparatively warmer and drier conditions in the summer and autumn months (NovApr; Fig 1b).

\subsection{Sample collection and preparation and chronology development}

A total of 57 cores (5-mm diameter) were collected from 20 trees from the Mickey Creek site in April 2010. Wherever possible, three cores per tree were collected. We also obtained 29 cores from 19 trees from the Mickey Creek site (collected in 1990) directly from the collectors, E. Cook and B. Buckley. Cores were prepared according to standard dendrochronological techniques (Stokes and Smiley, 1968) and visually crossdated before TRW was measured. This TRW data set was complemented with 27 TRW series from 27 trees collected by LaMarche and Campbell in 1975 (LaMarche et al., 1979) from the Pine Lake site (accessed from: https://www.ncdc.noaa.gov/paleo/study/3844; January 2009). In total 112 series from 66 trees were included in the final TRW chronology. 
We used signal-free methods (Melvin and Briffa, 2008) and an age-dependent spline (Melvin et al., 2007) to detrend each of the TRW series. We chose this method to retain a trend in the most recent part of the chronology that is similar to and likely related to a trend in observed temperatures over the same period. We used the RCSigFree program (http://www.Ideo.columbia.edu/tree-ringlaboratory/resources/software) to detrend the TRW series and calculated indices as residuals from power-transformed ring widths (Cook and Peters, 1997).

\subsubsection{Wood properties}

SilviScan-3, a rapid-assessment, high-resolution technology, which includes an image analyser, $\mathbf{x}$-ray densitometer and x-ray defractometer that was developed by the Commonwealth Scientific and Industrial Research Organisation, Australia (Evans, 1994), was used to measure mean density and TRD. In order to obtain measurements that are as accurate as possible, SilviScan-3 requires samples with minimal ring curvature. In addition, samples that have been heavily sanded such that relatively little of an original $5 \mathrm{~mm}$ core remains are not suitable for processing. Based on these constraints, a subset of 23 cores (15 trees) from the Mickey Creek 2010 collection and 6 cores ( 6 trees) from the Mickey Creek 1990 collection were selected for measurement of wood properties. These cores were cut into strips of $2 \mathrm{~mm}$ thickness in the tangential direction. For each core, mean density was measured by x-ray densitometry at $25 \mu \mathrm{m}$ intervals. TRD was also measured at $25 \mu \mathrm{m}$ intervals by image analysis of the transverse surface. CWT was derived from TRD and mean density. All variables were averaged over individual growth rings to provide mean density, mean TRD, and mean CWT for each year. The final mean density chronology included all 29 series from 21 trees. Some of the CWT series were excluded because they were not significantly correlated with the sample population; consequently the final CWT chronology included 24 series from 16 trees. The TRD series did not show a coherent growth signal so could not be used to develop a robust chronology and were not included in further analyses. 
Unlike the TRW series, there were no apparent trends in the recent decades of the mean density or

CWT series and we detrended these series using the locally-adaptive Friedman variable span smoother (Friedman, 1984) in the ARSTAN program (Cook and Krusic, n.d.). We calculated mean density and CWT indices as ratios because they showed stronger reconstruction skill compared with indices calculated using the residual method (data not shown; Cook and Peters, 1997). For further analyses, we used the ARSTAN chronologies (pooled autocorrelation added back into the residual chronology; Cook 1985). To assess the quality of our chronologies over time, we used the average correlation between series (RBAR) and expressed population signal (EPS) (Wigley et al., 1984). A minimum EPS value of 0.85 is generally accepted as a reasonable threshold for a reliable chronology.

\subsection{Climate Data}

Instrumental climate records in central Tasmania are sparse and often temporally short or discontinuous, particularly at high altitudes. The Australian Bureau of Meteorology (BOM) lists only two weather stations with temperature records within $100 \mathrm{~km}$ of the PLMC site and at comparable elevations (i.e., >1000 m.a.s.I.): Liawenee (1985-2013 C.E., with a discontinuity in 2001-2003 C.E. when the station was moved) at $17 \mathrm{~km}$ and Mt Read (1996-2014 C.E.) at $97 \mathrm{~km}$. The time series at these two stations are thus short and long-term temperature records for the PLMC site are limited to gridded data sets [e.g., CRU (Harris et al., 2014), AWAP (Raupach et al., 2012, 2009)], which are based almost entirely on low-elevation (<200 m.a.s.l.) weather station records. Both CRU and AWAP, however, have been adjusted for elevation; but topographical variability within a single grid square needs to be taken into consideration when using these data.

We determined the spatial extent of significant correlations between our tree-ring chronologies and a $0.5^{\circ}$ gridded data set of monthly averages of minimum, mean, and maximum temperatures (CRU TS 3.22; 1901-2013 C.E.; Mitchell and Jones, 2005) using the KNMI Climate Explorer (climexp.knmi.nl/; Trouet and van Oldenborgh, 2013). We then calculated regional temperature datasets (area-averaged gridded data) for the region with the strongest correlation (i.e., $41-43^{\circ} \mathrm{S}$, 

over the period of overlap (e.g., JanT $T_{\max }: r=0.88, p<0.001 ; 1985-2013$ C.E.). We used only the CRU TS 3.22 data from 1920 C.E. onwards, because few instrumental weather stations were operating in northern Tasmania prior to this date; consequently gridded data are likely not representative of actual temperatures for the region prior to 1920 C.E.

Precipitation and temperature in central Tasmania are strongly correlated in the growing season (particularly in January, $r=-0.47, p<0.0001 ; C R U$ TS 3.22) and correlations between tree growth at the Pine Lake-Mickey Creek site and temperature are generally much stronger than those between tree growth and precipitation (data not shown). Consequently, we focused solely on the relationship between tree growth and temperature in our analyses.

We further compared our tree-ring chronologies to data for broad-scale drivers that are known to influence summer climate in southeast Australia. The Southern Annular Mode (SAM) is the principal mode of circulation in the Southern Hemisphere and indicates the hemispheric-wide north-south movement of prevailing westerly winds over the Southern Ocean (Marshall, 2003). We used the British Antarctic Survey's SAM index (1957-2014 C.E.) in our analysis. We also obtained a monthly instrument-based SAM time series (1887-2004 C.E.) from the author (Visbeck, 2009). The intensity and position of the subtropical ridge (STR) have also been identified as major drivers of climate, particularly rainfall, in southeast Australia. The STR is a belt of high mean sea level pressure corresponding to the descending branch of the Hadley Circulation. We obtained an STR intensity index calculated by Drosdowsky (2005) updated to 2009 (Timbal and Drosdowsky, 2013), which indicates the intensity of the local maxima in monthly surface pressure along zonal profiles for a $5^{\circ}$ longitude band around $150^{\circ} \mathrm{E}$ between $10^{\circ} \mathrm{S}$ and $44^{\circ} \mathrm{S}$. 
significantly correlated with summer temperatures in central Tasmania and were not considered for further analyses.

\subsection{Tree growth-climate relationships}

174

We calculated Pearson correlation coefficients between the CWT, mean density, and TRW chronologies and monthly regional temperature variables (maximum, mean, and minimum) including the previous growing season (Sept to April) through to the end of the current growing season (Sept to April). Correlation coefficients were calculated over the 1920-2010 C.E. period. We did not remove linear trends from any of the time series and correlation values reflect both interannual and longer-term correlations among the series.

\subsection{Temperature reconstruction}

We developed two sets of linear models to regress climate variables against our chronologies - first, we used each of the individual detrended chronologies (mean density, CWT, and TRW) as a predictor in three separate models, and second, we used mean density and TRW as predictors in a stepwise linear regression model. CWT was excluded from the stepwise model selection because it explained less variance than mean density and was strongly correlated - and shared almost all of its explanatory power - with mean density. We explored models with current year $\left(t_{0}\right)$ predictors only and also models with both current and lagged $\left(t_{+1}\right)$ predictor variables to test for any lagged relationships between the proxy series and climate.

The integrity of the models was tested in PCReg (http://www.Ideo.columbia.edu/tree-ringlaboratory/resources/software) using split-period (1920-1959 and 1960-2010 C.E.) calibrationverification tests commonly used in dendroclimatology (Fritts, 1976; Cook and Kairiukstis, 1990). Two rigorous tests of fit, the reduction of error (RE) and the coefficient of efficiency (CE) were used to evaluate the skill of the models. RE estimates the goodness of fit between the observed and reconstructed values in the verification period, using the mean of observed values in the calibration period as a benchmark (Fritts, 1976). CE is calculated the same way as RE but uses the mean of 
observed values in the verification period as a benchmark (Cook et al., 1999). Positive values of each of these statistics indicate that a model is skilful in reconstructing observed variation in the climate target.

The Durbin-Watson (DW) statistic was calculated to test for first-order autocorrelation in the residuals of the final reconstruction model in R 3.2.0 ( $\mathrm{R}$ Core Team, 2015). We rescaled the variance of the reconstructed temperature data to match the variance of the observed temperature data, which allows comparisons between the magnitude of events in the past and those in the observed record. We used Loess curves to highlight low-frequency variability in reconstructed temperatures and calculated $95 \%$ prediction intervals for the linear models in R (R Core Team, 2015).

\subsection{Wavelet Analysis}

206

We calculated the wavelet spectrum of the mean density and TRW chronologies and the temperature reconstruction to examine frequency domain properties and how they changed over time (Torrence and Compo, 1998; http://www.ion.researchsystems.com/IONScript/wavelet). We selected the following options for our analysis: Morlet as the mother wavelet function; pad the ends with zeros; and a 10\% significance level using a white-noise background spectrum. We also calculated the wavelet coherence between our temperature reconstruction and the Mt Read reconstruction of summer temperatures in the biwavelet package (Gouhier, 2014) in R ( $R$ Core Team, 2015) using the following options: Morlet as the mother wavelet function; pad the ends with zeros; and a 5\% significance level.

\section{Results}

\subsection{Chronology and model development}

Both the mean density and CWT chronologies were 655 years long (1355-2010 C.E.). CWT was over the full period of overlap $(r=0.91 ; p<0.001)$. Both the mean density and CWT chronologies 
showed high common signal strength over the length of the chronology (RBAR $>0.3$; for mean density Fig. 3a-b; CWT data not shown). EPS values for the mean density chronology were higher than the 0.85 threshold from 1489 C.E. onwards. However, only one tree (with 3 radii) was included prior to 1513 C.E. (Fig. 3c) and tree-ring values prior to this date cannot be considered as reliable indicators of population-level tree-ring values because the growth of a single tree can easily be influenced by tree biology, localised disturbance or microsite conditions. We therefore selected the most reliable part of the mean density chronology based on sample depth (min. 3 trees) rather than EPS and we used only the 1530-2009 C.E. period in further analyses. EPS values for the CWT chronology showed similar temporal variation but were generally lower than for the mean density chronology and fell below the 0.85 threshold at several points prior to 1820 C.E. (data not shown). The TRW chronology extended back to 1277 C.E. with moderate signal strength (RBAR > 0.2) over the length of the chronology and is considered reliable (EPS > 0.85) from 1461 C.E. onwards (Fig. 3de). The mean density and TRW series show significant variability at different frequencies (Fig.4 a-d): mean density shows greater variability at high frequencies (2-16-year band) than TRW, but TRW shows greater variability than mean density at low frequencies (>64-year bands), particularly in the last two centuries, but this is potentially influenced by edge effects (Fig. 4a-d).

The mean density chronology was negatively correlated with regional maximum $\left(T_{\max }\right)$, mean $\left(T_{\text {mean }}\right)$, and minimum $\left(T_{\min }\right)$ temperatures over the summer months (December-April; Fig. 5a). Correlations with January temperatures in particular were much stronger than for other months: $T_{\max }, r=-0.66$; $T_{\text {mean }}, r=-0.64 ; T_{\min }, r=-0.54 ;$ all $p<0.0001$ (Fig. 5a). Correlations between CWT and temperature mirror those of mean density, but were generally slightly weaker (e.g., JanT $T_{\max }, r=-0.59, p<0.0001$; Fig. 5b). In contrast, TRW was positively correlated with temperatures in the summer-autumn months (e.g., JanT $T_{\max } r=0.24, p=0.02$; Fig. $5 c$ ), although this correlation is primarily driven by coherence in a positive long-term linear trend in both the TRW and JanT $\mathrm{max}_{\max }$ series, rather than a relationship on inter-annual timescales; when the data are linearly detrended, the relationship is not significant $(r=0.17, p=0.12)$. 
Based on the strongest tree-growth relationships identified above, we used JanT $T_{\max }$ and mean density as predictor and predictand respectively in our initial reconstruction model (mean densityonly model). This model demonstrated a good fit to the data $\left(R^{2}=0.43\right.$ for $1920-2009$ C.E.; Table 1$)$ and strong reconstruction skill (RE $>0$ ) (Table 1$)$ and the resulting reconstruction reproduces highfrequency variation in observed temperature well (Fig. 6). However, the more conservative CE test was not passed (CE < 0) for the late (1960-2010 C.E.) verification period (Table 1) due to a mismatch in the low-frequency trend between the mean density chronology and observed JanT $T_{\max }$ over the last century (Fig. 6). Observed JanT $\mathrm{T}_{\max }$ in central Tasmania increased linearly by $0.023^{\circ} \mathrm{C} \mathrm{yr}^{-1}(1920-2010$ C.E.; $p<0.0001$ ), but there was no significant linear trend in the mean density chronology over the same period $\left(-0.0003 \mathrm{yr}^{-1} ; \mathrm{p}=0.285\right)$ or the mean density-based reconstruction of $\operatorname{Jan}_{\max }\left(0.004^{\circ} \mathrm{C}\right.$ $\mathrm{yr}^{-1} ; \mathrm{p}=0.285 ;$ Fig. 6). The second model tested included only CWT as a predictor, which explained less variance in JanT $T_{\max }$ than the mean density-only model $\left(R^{2}=0.33\right)$ and similar to mean density, the CWT-only model also failed to reconstruct the long-term trend in Jan $T_{\max }(C E<0)$. A model using TRW as a sole predictor of current year's temperature explained only $6 \%$ of the variance in JanT $T_{\max }$. Despite some significant lagged correlations between proxies and temperature (Fig. 5), the inclusion of lagged $\left(t_{+1}\right)$ variables for the predictors (mean density, TRW or CWT) did not significantly improve model fit or the calibration and verification statistics for any of the three single-predictor models tested (data not shown). 
Table 1: Calibration, verification and fit statistics of linear models to reconstruct January maximum temperatures in central Tasmania. Linear models are based on mean density-only or on ring width (TRW) + mean density as predictors and use either the full period of data (1920-2010 C.E.) or a shorter period excluding the most recent years (1920-2003 C.E.) when an unexplained mismatch between the mean density chronology and observed temperatures occurred.

\begin{tabular}{cccccccc}
\multirow{2}{*}{ Predictor(s) } & \multicolumn{2}{c}{ Calibration } & \multicolumn{2}{c}{ Verification } & \multicolumn{2}{c}{ Reconstruction Model } \\
\cline { 2 - 8 } & Period & $\mathbf{R}^{\mathbf{2}}$ & Period & RE & CE & Period & $\mathbf{R}^{\mathbf{2}}$ \\
\hline \multirow{3}{*}{$\begin{array}{c}\text { Mean } \\
\text { density }\end{array}$} & $1960-2009$ & 0.34 & $1920-1959$ & 0.51 & 0.17 & \multirow{2}{*}{$1920-2009$} & \multirow{2}{*}{0.43} \\
\cline { 2 - 8 } & $1920-1959$ & 0.50 & $1960-2009$ & 0.41 & -0.01 & & \\
& $1960-2003$ & 0.45 & $1920-1959$ & 0.57 & 0.28 & \multirow{2}{*}{$1920-2003$} & 0.50 \\
\hline \multirow{4}{*}{ TRW+mean } & $1920-1959$ & 0.50 & $1960-2003$ & 0.50 & 0.19 & & \multirow{2}{*}{0.54} \\
density & $1960-2009$ & 0.40 & $1920-1959$ & 0.70 & 0.47 & \multirow{2}{*}{$1920-2009$} & \multirow{2}{*}{0.59} \\
\cline { 2 - 8 } & $1960-2003$ & 0.54 & $1920-1959$ & 0.67 & 0.44 & \multirow{2}{*}{$1920-2003$} & 0.59 \\
\hline
\end{tabular}

Note: $R^{2}$ is adjusted for the number of parameters in the models.

Next, we developed a stepwise linear regression model that included TRW in addition to mean density (TRW+mean density model). TRW is significantly positively correlated with JanT $T_{\max }$ in the current year $(r=0.24 ; p=0.02)$, but not with mean density $(r=0.06, p>0.1)$, suggesting that mean density and TRW explain different portions of the variation in observed temperature. The TRW+mean density model significantly improved the explanatory power (variance explained increased from 42.6 to $54.6 \% ; p<0.0001$ ) and also improved the verification statistics over the mean density-only model (Table 1). In particular, CE-values for the TRW+mean density model were positive for both calibration-verification periods, indicating that this model reliably reconstructs long-term variability evident in the observed temperature data. We thus used the TRW+mean density model for reconstructing past JanT $T_{\max }$ variability. There was significant but weak autocorrelation in the residuals of the TRW+mean density model at a 1-year time lag (DW $=1.51, p=$ $0.007 ; A R(1)=0.22)$. There was no significant autocorrelation in the residuals at lags longer than 1 year. The significant $A R(1)$ correlation did not obviously bias the errors associated with model parameter estimates. Nevertheless, we used a generalised least squares model with $A R(1)$ correlation structure in the nlme package (Pinheiro et al., 2015) in R (R Core Team, 2015) to reconstruct past temperature variability. 


\subsection{Reconstructed past temperature variability}

According to our reconstruction, extended periods (ca. 10 to 30 years) of cooler than average conditions have occurred in the past 480 years (e.g., mid 1700s, late 1800 s and early 1900s) and the 60-year period since 1950 C.E. has been warmer than average (Fig 7a). Although our reconstruction is not directly comparable with the Mt Read reconstruction of Cook et al. (2000; Fig. 7b) owing to the different temperature data used in each reconstruction [i.e., different seasons (Jan vs. Nov-Apr), variables ( $T_{\max }$ vs. $T_{\text {mean }}$ ), and sources (CRU gridded data for central Tasmania vs. station data from across Tasmania)], there is significant coherence between the two reconstructions on annual to decadal timescales over their common period (1530-1991 C.E.; Fig 7c) and also on centennial timescales over the last century but this is potentially influenced by edge effects (Fig 7c). Periods of below average temperature are revealed in both reconstructions in the late 1800s and early 1900s (i.e., 50-year Loess curve below the long-term mean; Fig. 7a-b). Both reconstructions also show that the post-1950 C.E. period has been warmer than average (50-year Loess curve above the long-term mean) due to a low frequency of cold summers (i.e., $\operatorname{JanT}_{\max }<18^{\circ} \mathrm{C}$ or $\operatorname{SummerT}_{\text {mean }}<15^{\circ} \mathrm{C}$; Fig. $7 \mathrm{a}-$ b).

Significant high-frequency variability exists intermittently in the reconstruction (i.e., 2-8-year and 16-32-year bands; Fig. 4e-f). A ca. 40-year period of reduced high-frequency variability occurred in the early 1800 s when reconstructed temperatures were generally within $1^{\circ} \mathrm{C}$ of the long-term average (i.e., $18-20^{\circ} \mathrm{C}$; Figs. $4 \mathrm{e}$ and $7 \mathrm{a}$ ). Reduced high-frequency variability also occurred post-1950 when reconstructed JanT $T_{\max }$ was consistently $>18^{\circ} \mathrm{C}$ (Figs. $4 \mathrm{e}$ and 7a). There is also evidence of centennial-scale (ca. 128-year band) variance in the last two centuries (Fig. 4e-f), but this must be cautiously interpreted due to padding of the end of the series. High frequency variability observed in the TRW+mean density reconstruction is consistent with high-frequency variability evident in only the mean density chronology (Fig 4a-b), while low (ca. 128-year band) frequency variability in the reconstruction is consistent with low frequency variability in the TRW chronology (Fig. 4c-d). 
Our reconstruction of early summer temperatures in Tasmania was positively correlated with the STR intensity index in the summer season (Dec-Feb) on annual timescales (high-pass filtered, 20-year Loess curve; $r=0.30, p=0.009 ; 1890-2009$ C.E.) and also shows considerable agreement with the STR intensity index on decadal timescales (Fig. S1). These relationships were particularly strong in January (high pass, $r=0.40, p<0.0001$ ). Our reconstruction was also positively correlated on annual timescales (high-pass filtered, 20-year Loess curve) - but showed little agreement on decadal timescales - with the instrumental SAM index (BAS) $(r=0.27, p=0.048,1957-2009$ C.E.; Fig. S1) and an instrument-based reconstruction of the SAM (Visbeck; $r=0.24, p=0.01,1887-2004$ C.E.; Fig. S1) in the summer season (Dec-Feb).

\section{Discussion}

\subsection{Wood density as a proxy for temperature in southeastern Australia}

Wood density contains a strong inter-annual climate signal, but failed to reproduce a long-term trend evident in the observed temperature. The absence of a long-term trend in the mean density chronology is largely attributable to a series of three years in the last decade $(2005,2006,2007)$ when mean density values were much higher than average, albeit not extreme. However, if mean density is used as the sole predictor of temperature, the resulting reconstruction underestimates observed temperatures in these years by $>2^{\circ} \mathrm{C}$ (Fig. 6) and as a result fails to verify (CE $<0$; Table 1 ). If this period (i.e., 2004-2010 C.E.) is excluded from the model calibration and verification, the CE (and all other tests of model fit) improve (Table 1) and the slope of the linear trend increases from $0.004 \mathrm{yr}^{-1}$ (1920-2010 C.E.) to $0.013^{\circ} \mathrm{C}^{-1}$ (1920-2003 C.E.; $p=0.05$; Fig. 6), confirming that the mismatch between JanT $T_{\max }$ and mean density in these years is principally responsible for nonverification ( $C E<0$ ) of the mean density-only model. The exclusion of the 2004-2010 C.E. period

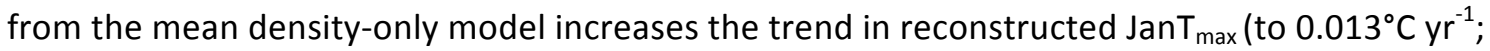
1920-2003 C.E.), but still underestimates the trend apparent in the observed temperature data 
$335\left(0.024^{\circ} \mathrm{C}^{-1}\right)$ over the same period. Consequently, mean density alone appears to be unable to robustly reconstruct long-term variability in observed temperatures.

The reason for the discrepancy between the mean density chronology and observed temperatures in these particular years in the last decade remains unclear. It is possible that this discrepancy is a measurement error or outlier, but unlikely because more than half of the sampled trees exhibited high density in these years. Temperatures at the nearby Liawenee climate station are similar to those of the gridded temperature data used to verify our reconstruction model so it is unlikely that the accuracy of the gridded data is the cause of this mismatch. In addition, there is no evidence of unusual conditions (daily level) in the instrumental precipitation or temperature record that may help explain higher than average ring density in these years. There is also no evidence of disease nor has the site been recently disturbed. Without knowing the cause of the mismatch between observed and reconstructed temperatures in the most recent decade we must provide the caveat that similar issues have possibly occurred in other periods of the reconstruction and the reconstruction should be interpreted with this in mind.

The inclusion of TRW with mean density as a predictor of temperature improves the coherence of the linear trend in the reconstruction to that of the observed temperature data (i.e, reconstructed trend of $0.020^{\circ} \mathrm{C}^{-1}$ compared to observed trend of $0.023^{\circ} \mathrm{C}^{-1}$; $\left.1920-2010 \mathrm{C} . \mathrm{E}.\right)$; however, the mismatch between these years of unusually high mean density values (low reconstructed temperatures) and observed temperatures in the last decade remains obvious on both the interannual and longer-term scale in the final reconstruction (Fig. 7). The exclusion of the 2004-2010 C.E. period model improves model fit for the TRW-mean density model (Table 1), but tends to overestimate the increasing trend in observed $\operatorname{JanT}_{\max }$ (i.e., reconstructed linear trend of $0.027^{\circ} \mathrm{C} \mathrm{yr}^{-1}$ over 1920-2003 C.E.). Because of this and because we do not know of a non-climatic reason for the mismatch between observed temperatures and the mean density chronology in 2005-2007 C.E., we have not excluded these years from the final TRW+mean density model. 
In contrast to studies in North America and Europe where density (particularly maximum latewood density, MXD) is positively related to summer temperatures, we found that mean density of Athrotaxis is negatively related to summer temperatures in Tasmania (Fig. 5). Drew et al. (2013) also found a negative relationship between wood density (mean ring density and mean latewood density) and summer temperatures in Huon Pine at low elevations in Tasmania. The physiological mechanism underlying this unusual negative relationship between temperature and tree-ring density in some Tasmanian conifers has not yet been investigated. However, CWT and thus density in conifers is generally closely related to the duration and rate of cell wall thickening, which is influenced by temperature (Wodzicki, 1971; Uggla et al., 2001; Rossi et al., 2006) and cell walls in conifers have been shown to be thinner when differentiation occurs under warmer conditions (Denne, 1971; Antonova and Stasova, 1993; 1997). It is possible that warmer mid-summer (January) temperatures in central Tasmania could result in thinner cell walls and hence lower ring density. This mechanism has also been invoked to explain the negative relationship between temperature and wood density in Huon Pine, also in Tasmania (Drew et al. 2013). In contrast, a number of studies based on high elevation Northern Hemisphere sites have found that low rather than high temperatures usually limit cell wall development and tree growth during the growing season (Briffa et al., 2002; Rossi et al., 2008).

We found that mean density of $A$. cupressoides shows greater variability at high frequencies (2-16year bands; Fig. 4a-b) than TRW, but TRW shows greater variability at low frequencies (64-128-year bands), particularly over the last two centuries (Fig. 4c-d). This finding is consistent with other studies, which have shown that density generally contains stronger inter-annual variation and weaker low-frequency variation than TRW (Schweingruber et al., 1979; D'Arrigo et al., 1992; Frank and Esper, 2005; Frank et al., 2007; Büntgen et al., 2010). TRW tends to integrate effects from the previous year's climatic and environmental conditions, which can lead to differing signal-to-noise 
complementary high- and low-frequency signals in mean density and TRW, respectively, to produce a robust reconstruction of past temperatures (Figs. 4e and 7a).

\subsection{Past temperature variability in southeastern Australia}

388

389

390

391

Periods of lower-than-average early summer temperature in the late 1800 s and early 1900 s in our reconstruction coincide with the coldest period (1890-1960 C.E.) in the Mt Read reconstruction of summer mean temperatures (Fig. 7) and a general cooling trend in most regions of the world in the late $19^{\text {th }}$ Century (PAGES 2k Consortium, 2013). Similarly, post-1950 warming in our reconstruction is consistent with the warming trend in the Mt Read TRW-based temperature reconstruction (Fig 7; Cook et al., 1991; Cook et al., 1992; Cook et al., 2000), an observed increase in growth in Halocarpus in New Zealand (Villalba et al., 2012), and broad-scale warming in the Southern Hemisphere over the same period (PAGES 2k Consortium, 2013). This recent warm period appears to be attributed to a decrease in the frequency and magnitude of cold summers rather than an increase in the frequency and/or magnitude of warm summers (Fig. 7). This is consistent with observed recent and projected near-term declines in the frequency of cold days in Australia (Alexander and Arblaster, 2009) and globally (Kirtman et al., 2013).

Recent trends in hemispheric (i.e., the SAM) and regional (i.e., the STR) circulation features are likely to have played a role in the observed increasing trend in summer temperatures in central Tasmania over the last half century. In the Austral summer, the STR is usually in its most southerly position, south of the Australian continent. In this position, the high-pressure systems along the STR tend to block (or weaken) mid-latitude frontal systems from reaching southeastern Australia, bringing warmer and drier conditions to the region (Australian Bureau of Meteorology, 2008). Stronger intensities of the STR have also been linked to suppressed rainfall over the region (Murphy and Timbal, 2008; Larsen and Nicholls, 2009; Timbal and Drosdowsky, 2013). Winter (Jul-Sep) is the dominant season of influence of the STR in mainland southeastern Australia; however, in Tasmania, the relationship between the intensity of the STR and rainfall is significant in all seasons and 

intensity in the summer season have been more variable than in other seasons, but a consistent increasing trend is evident since at least the mid-1970s (Timbal and Drosdowsky, 2013; Fig S1). The strong correlation between our reconstruction of early summer temperatures and the STR intensity index suggests that the increasing intensity of the STR over recent decades may have contributed to the unusual warm period observed in central Tasmania over the last half century.

Regional surface air temperatures in Tasmania are also strongly influenced by the behaviour of the Southern Hemisphere westerly winds (Taschetto and England, 2009). During a positive phase of the SAM, the band of prevailing westerly winds and storms contracts towards Antarctica and weakens over southern Australia, causing warm and anomalously dry conditions in Tasmania (Gillett et al., 2006; Australian Bureau of Meteorology, 2008). Importantly, since the 1990s in particular there has been an increasing dominance and strengthening of the positive phase of the SAM (Thompson et al., 2011; Fig S1). This unusual behaviour of the SAM has been implicated as a driver of recent trends in rainfall in several regions of Australia (Cai and Cowan, 2006; Taschetto and England, 2009; Fierro and Leslie, 2013; Lavender and Abbs, 2013; Raut et al., 2014; O'Donnell et al., 2015). The significant correlations between our reconstruction and the SAM over the last century suggest that the period weakening of the prevailing westerly winds over Tasmania.

\section{Conclusions}

Our findings highlight the potential to use the complementary climate signals in TRW and mean density to provide a more complete picture of inter-annual to centennial-scale variation in past temperatures in southeastern Australia. The relative weakness of the TRW signal alone meant, until now, it has not been possible to reconstruct temperatures from $A$. cupressoides. Wood density 
provides new opportunities for successful temperature reconstructions in southeastern Australia from tree species in which TRW is only weakly correlated with temperature. Both our TRW+mean density-based JanT $_{\max }$ reconstruction and the Mt Read TRW-based mean summer temperature reconstruction show that summer temperatures in Tasmania have generally been warmer in the last half century than in the previous five centuries, coincident with broad-scale temperature increases in the Southern and Northern Hemispheres. Warmer temperatures in central Tasmania in the last half-century may be related to shifts in the behaviour of Southern Hemisphere circulation features (i.e., the increasing dominance of the positive SAM and the intensification of the STR). Significant correlations between our reconstruction and these circulation features in the Southern Hemisphere also suggest that tree-ring reconstructed temperatures from Tasmania reflect broad-scale climate variability in the temperate latitudes of the Southern Hemisphere.

\section{Acknowledgements}

This research was funded by an Australian Research Council Discovery Project grant (DP120104320 to PJB). We are grateful to Michael Goddard for assistance in preparing core samples for analysis, Scott Nicholls for assistance in preparing and analysing samples, and the participants of the Dendroclimatology Masterclass as part of WorldDendro2014: Anders Brundin, Binod Dawadi, Nathan English, Maarit Kalela-Brundin, Robert Kennedy, Kathelyn Paredes, and Meritxell RamirezOlle. We are also grateful to Wasyl Drosdowsky for providing the STR intensity index data and Martin Visbeck for providing the monthly instrument-based reconstruction of the SAM. Lamont-Doherty

\section{References}

Alexander, L. V, Arblaster, J.M., 2009. Assessing trends in observed and modelled climate extremes over Australia in relation to future projections. Int. J. Climatol. 29, 417-435. doi:10.1002/joc.1730

Allen, K., Drew, D.M., Downes, G.M., Evans, R., Baker, P., Grose, M., 2012. Ring width, climate and wood density relationships in two long-lived Tasmanian tree species. Dendrochronologia 30, 167-177. doi:http://dx.doi.org/10.1016/j.dendro.2010.12.006

Allen, K., Francey, R., Michael, K., Nunez, M., 1999. A structural time series approach to the reconstruction of Tasmanian maximum temperatures. Environ. Model. Softw. 14, 261-274. doi:10.1016/S1364-8152(98)00078-4

Allen, K.J., Cook, E.R., Buckley, B.M., Larsen, S.H., Drew, D.M., Downes, G.M., Francey, R.J., Peterson, M.J., Baker, P.J., 2014. Continuing upward trend in Mt Read Huon pine ring widths - 
Allen, K.J., Drew, D.M., Downes, G.M., Evans, R., Cook, E.R., Battaglia, M., Baker, P.J., 2013. A strong regional temperature signal in low-elevation Huon pine. J. Quat. Sci. 28, 433-438. doi:10.1002/jqs.2637

Allen, K.J., Nichols, S.C., Evans, R., Cook, E.R., Allie, S., Carson, G., Ling, F., Baker, P.J., 2015. Preliminary December-January inflow and streamflow reconstructions from tree rings for western Tasmania, southeastern Australia. Water Resour. Res. 51, 5487-5503. doi:10.1002/2015WR017062

Allen, K.J., Ogden, J., Buckley, B.M., Cook, E.R., Baker, P.J., 2011. The potential to reconstruct broadscale climate indices associated with southeast Australian droughts from Athrotaxis species, Tasmania. Clim. Dyn. 37, 1799-1821. doi:10.1007/s00382-011-1011-7

Antonova, G.F., Stasova, V. V., 1997. Effects of environmental factors on wood formation in larch (Larix sibirica Ldb.) stems. Trees 11, 462-468. doi:10.1007/PL00009687

Antonova, G.F., Stasova, V. V., 1993. Effects of environmental factors on wood formation in Scots pine stems. Trees 7, 214-219.

Australian Bureau of Meteorology, 2008. Australian Climate Influences [WWW Document]. URL http://www.bom.gov.au/watl/about-weather-and-climate/australian-climate-influences.shtml (accessed 3.26.15).

Brienen, R.J.W., Helle, G., Pons, T.L., Guyot, J.-L., Gloor, M., 2012. Oxygen isotopes in tree rings are a good proxy for Amazon precipitation and El Niño-Southern Oscillation variability. Proc. Natl. Acad. Sci. 109, 16957-16962. doi:10.1073/pnas.1205977109

Briffa, K., Jones, P., Schweingruber, F., 1992. Tree-ring density reconstructions of summer temperature patterns across western North America since 1600. J. Clim. 5, 735-754.

Briffa, K.R., Osborn, T.J., Schweingruber, F.H., Jones, P.D., Shiyatov, S.G., Vaganov, E. a., 2002. Treering width and density data around the Northern Hemisphere: Part 1, local and regional climate signals. The Holocene 12, 737-757. doi:10.1191/0959683602hl587rp

Brookhouse, M., Brack, C., 2006. Crossdating and analysis of eucalypt tree rings exhibiting terminal and reverse late wood. Trees 20, 767-781.

Brookhouse, M., Lindesay, J., Brack, C., 2008. The potential of tree rings in Eucalyptus pauciflora for climatological and hydrological reconstruction. Geogr. Res. 46, 421-434.

Buckley, B.M., Cook, E.R., Peterson, M.J., Barbetti, M., 1997. A changing temperature response with elevation for Lagarostrobos franklinii in Tasmania, Australia, in: Climatic Change at High Elevation. Springer, Netherlands, pp. 245-266.

Büntgen, U., Frank, D., Trouet, V., Esper, J., 2010. Diverse climate sensitivity of Mediterranean treering width and density. Trees 24, 261-273. doi:10.1007/s00468-009-0396-y

Cai, W., Cowan, T., 2006. SAM and regional rainfall in IPCC AR4 models: Can anthropogenic forcing account for southwest Western Australian winter rainfall reduction? Geophys. Res. Lett. 33, L24708. doi:10.1029/2006gl028037

Cook, E., Bird, T., Peterson, M., Barbetti, M., Buckley, B., D’Arrigo, R., Francey, R., 1992. Climatic change over the last millennium in Tasmania reconstructed from tree-rings. The Holocene 2, 205-217. doi:10.1177/095968369200200302

Cook, E., Bird, T., Peterson, M., Barbetti, M., Buckley, B., D’Arrigo, R., Francey, R., Tans, P., 1991. Climatic Change in Tasmania inferred from a 1089-year tree-ring chronology of Huon Pine. 
Cook, E.R., Buckley, B.M., D'Arrigo, R.D., Peterson, M.J., 2000. Warm-season temperatures since $1600 \mathrm{BC}$ reconstructed from Tasmanian tree rings and their relationship to large-scale sea surface temperature anomalies. Clim. Dyn. 16, 79-91. doi:10.1007/s003820050006

Cook, E.R., Kairiukstis, L.A., 1990. Methods of Dendrochronology - Applications in the Environmental Sciences. Kluwer Academic Publishers, Dordrecht, The Netherlands.

Cook, E.R., Krusic, P.J., n.d. Program ARSTAN, A tree-ring standardization program based on detrending and autoregressive time series modeling with interactive graphics.

Cook, E.R., Meko, D.M., Stahle, D.W., Cleaveland, M.K., 1999. Drought Reconstructions for the Continental United States*. J. Clim. 12, 1145.

Cook, E.R., Peters, K., 1997. Calculating unbiased tree-ring indices for the study of climatic and environmental change. The Holocene 7, 361-370. doi:10.1177/095968369700700314

Cullen, L.E., Grierson, P.F., 2009. Multi-decadal scale variability in autumn-winter rainfall in southwestern Australia since $1655 \mathrm{AD}$ as reconstructed from tree rings of Callitris columellaris (Cupressaceae). Clim. Dyn. 33, 433-444.

D’Arrigo, R., Baker, P., Palmer, J., Anchukaitis, K., Cook, G., 2008. Experimental reconstruction of monsoon drought variability for Australasia using tree rings and corals. Geophys. Res. Lett. 35, L12709. doi:10.1029/2008gl034393

D'Arrigo, R., Jacoby, G., Free, R., 1992. Tree-ring width and maximum latewood density at the North American tree line: parameters of climatic change. Can. J. For. Res. 22, 1290-1296.

Davi, N.K., Jacoby, G.C., Wiles, G.C., 2003. Boreal temperature variability inferred from maximum latewood density and tree-ring width data, Wrangell Mountain region, Alaska. Quat. Res. 60, 252-262. doi:10.1016/j.yqres.2003.07.002

Denne, M.P., 1971. Temperature and Tracheid Development in Pinus sylvestris Seedlings. J. Exp. Bot. $22,362-370$.

Drew, D.M., Allen, K., Downes, G.M., Evans, R., Battaglia, M., Baker, P., 2013. Wood properties in a long-lived conifer reveal strong climate signals where ring-width series do not. Tree Physiol. 33, 37-47. doi:10.1093/treephys/tps111

Drosdowsky, W., 2005. The latitude of the subtropical ridge over eastern Australia: The $L$ index revisited. Int. J. Climatol. 25, 1291-1299. doi:10.1002/joc.1196

Evans, R., 1994. Rapid Measurement of the Transverse Dimensions of Tracheids in Radial Wood Sections from Pinus Radiata. Holzforschung 48, 168-172.

Farjon, A., 2005. A Monograph of Cupressaceae and Sciadopitys. Royal Botanic Gardens, Kew, UK.

Fierro, A.O., Leslie, L.M., 2013. Links between central west Western Australian rainfall variability and large-scale climate drivers. J. Clim. 26, 2222-2246. doi:10.1175/jcli-d-12-00129.1

Frank, D., Büntgen, U., Böhm, R., Maugeri, M., Esper, J., 2007. Warmer early instrumental measurements versus colder reconstructed temperatures: shooting at a moving target. Quat. Sci. Rev. 26, 3298-3310. doi:10.1016/j.quascirev.2007.08.002

Frank, D., Esper, J., 2005. Characterization and climate response patterns of a high-elevation, multispecies tree-ring network in the European Alps. Dendrochronologia 22, 107-121. doi:10.1016/j.dendro.2005.02.004

Friedman, J.H., 1984. A Variable Span Smoother. Technical Report No. 5, Laboratory for 
Fritts, H.C., 1976. Tree Rings and Climate. Academic Press, London.

Gillett, N.P., Kell, T.D., Jones, P.D., 2006. Regional climate impacts of the Southern Annular Mode. Geophys. Res. Lett. 33. doi:10.1029/2006GL027721

Gouhier, T., 2014. biwavelet: conduct univariate and bivariate wavelet analyses. R Package Version 0.17.04. Available from http://github.com/tgouhier/biwavelet.

Grudd, H., 2008. Torneträsk tree-ring width and density ad 500-2004: a test of climatic sensitivity and a new 1500-year reconstruction of north Fennoscandian summers. Clim. Dyn. 31, 843-857. doi:10.1007/s00382-007-0358-2

Harris, I., Jones, P.D., Osborn, T.J., Lister, D.H., 2014. Updated high-resolution grids of monthly climatic observations - the CRU TS3.10 dataset. Int. J. Climatol. 34, 623-642.

Heinrich, I., Weidner, K., Helle, G., Vos, H., Lindesay, J., Banks, J.G., 2009. Interdecadal modulation of the relationship between ENSO, IPO and precipitation: insights from tree rings in Australia. Clim. Dyn. 33, 63-73. doi:10.1007/s00382-009-0544-5

Kirtman, B., Power, S.B., Adedoyin, A.J., Boer, G.J., Bojariu, R., Camilloni, I., Doblas-Reyes, F., Fiore, A.M., Kimoto, M., Meehl, G., Prather, M., Sarr, A., Schär, C., Sutton, R., van Oldenborgh, G., Vecchi, G., Wang, H.-J., 2013. Near-term Climate Change: Projections and Predictability, in: Stocker, T.F., Qin, D., Plattner, G.-K., Tignor, M., Allen, S.K., Boschung, J., Nauels, A., Xia, Y., Bex, V., Midgley, P.M. (Eds.), Climate Change 2013: The Physical Science Basis. Contribution of Working Group I to the Fifth Assessment Report of the Intergovernmental Panel on Climate Change. Cambridge University Press, Cambridge, UK, and New York, NY, USA, pp. 953-1028. doi:10.1017/СBO9781107415324.023

LaMarche, V.C., Holmes, R.L., Dunwiddie, P.W., Drew, L.G., 1979. Tree-ring chronologies of the Southern Hemisphere. Volume 4: Australia, Chronology Series V. Laboratory of Tree-Ring Research, University of Arizona, Tucson, AZ.

Larsen, S.H., Nicholls, N., 2009. Southern Australian rainfall and the subtropical ridge: Variations interrelationships, and trends. Geophys. Res. Lett. 36, 1-5. doi:10.1029/2009GL037786

Lavender, S., Abbs, D., 2013. Trends in Australian rainfall: contribution of tropical cyclones and closed lows. Clim. Dyn. 40, 317-326. doi:10.1007/s00382-012-1566-y

Luckman, B.H., Wilson, R.J.S., 2005. Summer temperatures in the Canadian Rockies during the last millennium: a revised record. Clim. Dyn. 24, 131-144. doi:10.1007/s00382-004-0511-0

Marshall, G.J., 2003. Trends in the Southern Annular Mode from observations and reanalyses. J. Clim. 16, 4134-4143.

Melvin, T.M., Briffa, K.R., 2008. A "signal-free" approach to dendroclimatic standardisation. Dendrochronologia 26, 71-86.

Melvin, T.M., Briffa, K.R., Nicolussi, K., Grabner, M., 2007. Time-varying-response smoothing. Dendrochronologia 25, 65-69. doi:http://dx.doi.org/10.1016/j.dendro.2007.01.004

Mitchell, T.D., Jones, P.D., 2005. An improved method of constructing a database of monthly climate observations and associated high-resolution grids. Int. J. Climatol. 25, 693-712.

Murphy, B.F., Timbal, B., 2008. A review of recent climate variability and climate change in southeastern Australia. Int. J. Climatol. 28, 859-879. doi:10.1002/joc.1627

O’Donnell, A.J., Cook, E.R., Palmer, J.G., Turney, C.S.M., Page, G.F.M., Grierson, P.F., 2015. Tree Rings Show Recent High Summer-Autumn Precipitation in Northwest Australia Is Unprecedented 
PAGES $2 \mathrm{k}$ Consortium, 2013. Continental-scale temperature variability during the past two millennia. Nat. Geosci. 6, 339-346. doi:10.1038/NGEO1797

Palmer, J.G., Cook, E.R., Turney, C.S.M., Allen, K., Fenwick, P., Cook, B.I., O’Donnell, A., Lough, J., Grierson, P., Baker, P., 2015. Drought variability in the eastern Australia and New Zealand summer drought atlas (ANZDA, CE 1500-2012) modulated by the Interdecadal Pacific Oscillation. Environ. Res. Lett. 10, 124002. doi:10.1088/1748-9326/10/12/124002

Pinheiro, J., Bates, D., DebRoy, S., Sarkar, D., 2015. Linear and Nonlinear Mixed Effects Models. R Package version 3.1-125. Available from: http://CRAN.R-project.org/package=nlme.

Poussart, P.M., Myneni, S.C.B., Lanzirotti, A., 2006. Tropical dendrochemistry: A novel approach to estimate age and growth from ringless trees. Geophys. Res. Lett. 33, L17711. doi:10.1029/2006gl026929

R Core Team, 2015. R: a language and environment for statistical computing. R Foundation for Statistical Computing, Vienna, Austria. http://www.R-project.org/.

Raupach, M.R., Briggs, P.R., Haverd, V., King, E.A., Paget, M., Trudinger, C.M., 2012. Australian Water Availability Project (AWAP) [WWW Document]. CSIRO Mar. Atmos. Res. Canberra, Aust. URL http://www.csiro.au/awap

Raupach, M.R., Briggs, P.R., Haverd, V., King, E.A., Paget, M., Trudinger, C.M., 2009. Australia Water Availability Project (AWAP): CSIRO Marine and Atmospheric Research Component: Final Report for Phase 3.

Raut, B.A., Jakob, C., Reeder, M.J., 2014. Rainfall changes over southwestern Australia and their relationship to the Southern Annular Mode and ENSO. J. Clim. 27, 5801-5814. doi:10.1175/JCLI-D-13-00773.1

Rossi, S., Deslauriers, A., Anfodillo, T., 2006. Assessment of cambial activity and xylogenesis by microsampling tree species: an example at the Alpine timberline. lawa J. 27, 383-394.

Rossi, S., Deslauriers, A., Griçar, J., Seo, J.-W., Rathgeber, C.B., Anfodillo, T., Morin, H., Levanic, T., Oven, P., Jalkanen, R., 2008. Critical temperatures for xylogenesis in conifers of cold climates. Glob. Ecol. Biogeogr. 17, 696-707. doi:10.1111/j.1466-8238.2008.00417.x

Schweingruber, F., Briffa, K., 1996. Tree-ring density networks for climate reconstruction, in: Jones, P.D., Bradley, R.S. (Eds.), Climatic Variations and Forcing Mechanisms of the Last 2000 Years. Springer-Verlag Berline Heidelberg, pp. 43-66.

Schweingruber, F.H., 1992. Annual growth rings and growth zones in woody plants in southern Australia. IAWA Bull. 13, 359-379.

Schweingruber, F.H., Braker, O.U., Schar, E., 1979. Dendroclimatic studies on conifers from central Europe and Great Britain. Boreas 8, 427-452.

Stokes, M.A., Smiley, T.L., 1968. An Introduction to Tree-Ring Dating. The University of Chicago Press, Chicago, USA.

Taschetto, A.S., England, M.H., 2009. An analysis of late twentieth century trends in Australian rainfall. Int. J. Climatol. 29, 791-807. doi:10.1002/joc.1736

Thompson, D.W.J., Solomon, S., Kushner, P.J., England, M.H., Grise, K.M., Karoly, D.J., 2011. Signatures of the Antarctic ozone hole in Southern Hemisphere surface climate change. Nat. Geosci. 4, 741-749.

Timbal, B., Drosdowsky, W., 2013. The relationship between the decline of Southeastern Australian 
rainfall and the strengthening of the subtropical ridge. Int. J. Climatol. 33, 1021-1034. doi:10.1002/joc.3492

Torrence, C., Compo, G.P., 1998. A Practical Guide to Wavelet Analysis. Bull. Am. Meteorol. Soc. 79, 61-78.

Treydte, K.S., Schleser, G.H., Helle, G., Frank, D.C., Winiger, M., Haug, G.H., Esper, J., 2006. The twentieth century was the wettest period in northern Pakistan over the last millennium. Nature 440, 1179-1182.

Trouet, V., 2014. A tree-ring based late summer temperature reconstruction (AD 1675-1980) for the northeastern Mediterranean. Radiocarbon 56, S69-S78.

Trouet, V., Panayotov, M., Ivanova, a., Frank, D., 2012. A pan-European summer teleconnection mode recorded by a new temperature reconstruction from the northeastern Mediterranean (AD 1768-2008). The Holocene 22, 887-898. doi:10.1177/0959683611434225

Trouet, V., van Oldenborgh, G.J., 2013. KNMI Climate Explorer: a web-based research tool for highresolution paleoclimatology. Tree-Ring Res. 69, 3-13.

Tuovinen, M., McCarroll, D., Grudd, Håk., Jalkanen, R., Los, S., 2009. Spatial and temporal stability of the climatic signal in northern Fennoscandian pine tree-ring width and maximum density. Boreas 38, 1-12. doi:10.1111/j.1502-3885.2008.00046.x

Uggla, C., Magel, E., Moritz, T., Sundberg, B., 2001. Function and dynamics of auxin and carbohydrates during earlywood/latewood transition in Scots pine. Plant Physiol. 125, 20252039.

Vance, T.R., Roberts, J.L., Plummer, C.T., Kiem, a S., Ommen, T.D. Van, 2015. Interdecadal Pacific variability and eastern Australian megadroughts over the last millennium. Geophys. Res. Lett. 10.1002/2014GL062447. doi:10.1002/2014GL062447

Villalba, R., Lara, A., Masiokas, M.H., Urrutia, R., Luckman, B.H., Marshall, G.J., Mundo, I.A., Christie, D.A., Cook, E.R., Neukom, R., Allen, K., Fenwick, P., Boninsegna, J.A., Srur, A.M., Morales, M.S., Araneo, D., Palmer, J.G., Cuq, E., Aravena, J.C., Holz, A., LeQuesne, C., 2012. Unusual Southern Hemisphere tree growth patterns induced by changes in the Southern Annular Mode. Nat. Geosci. 5, 793-798. doi:doi:10.1038/ngeo1613

Visbeck, M., 2009. A station-based Southern Annular Mode index from 1884 to 2005. J. Clim. 22, 940-950. doi:10.1175/2008JCLI2260.1

Whinder, F., Clarke, K.L., Warwick, N.W.M., Gasson, P.E., 2013. Structural diversity of the wood of temperate species of Acacia s.s. (Leguminosae: Mimosoideae). Aust. J. Bot. 61, 291. doi:10.1071/BT13053

Wigley, T.M.L., Briffa, K.R., Jones, P.D., 1984. On the average value of correlated time series, with applications in dendroclimatology and hydrometeorology. J. Clim. Appl. Meteorol. 23, 201-213.

Wilson, R., D’Arrigo, R., Buckley, B., Büntgen, U., Esper, J., Frank, D., Luckman, B., Payette, S., Vose, R., Youngblut, D., 2007. A matter of divergence: Tracking recent warming at hemispheric scales using tree ring data. J. Geophys. Res. 112, D17103. doi:10.1029/2006JD008318

Wodzicki, T.J., 1971. Mechanism of xylem differentiation in Pinus silvestris L. J. Exp. Bot. 22, 670687. 
680 Fig 1. Location and climate of the Pine Lake-Mickey Creek (PLMC) site in Central Tasmania, Australia. (a) Locations of the PLMC site (circle), nearest high-altitude climate stations (squares; 1. Liawenee and 2. Mt Read) and cities (triangles). The location of the Mt Read climate station [2] is also the approximate location of the site used to develop the existing Mt Read temperature reconstruction. (b) Average monthly precipitation (bars) and mean (black line), maximum (upper grey line), and minimum (lower grey line) temperatures of central Tasmania (CRU TS3.22 $0.5^{\circ}$ gridded datasets area-averaged over $41-43^{\circ} \mathrm{S}, 145.5-147.5^{\circ} \mathrm{E}$ and temporally-averaged over $1920-$ 2013)

[1 Column width]

Fig 2: Significant $(p<0.05)$ correlations between the Pine Lake-Mickey Creek (PLMC) mean density chronology and $T_{\max }$ in (a) summer-autumn (Dec-May) and (b) January between 1920 and 2010 C.E. in Tasmania, Australia. Black dot indicates the location of the PLMC site. Black square indicates the area over which gridded temperature data were averaged to create a regional temperature dataset. Images produced in climate explorer (climexp.knmi.nl)

Fig. 3: Mean ring density (a-c) and ring width (TRW; d-f) chronologies of Athrotaxis cupressoides. (a) mean density index, (b) measures of signal strength, the $\bar{R}$ (RBAR) and the expressed population signal (EPS) of the mean density chronology, and (c) sample depth of the mean density chronology. (d) TRW index, (e) the $\bar{R}$ and EPS and (f) sample depth of the TRW chronology. Grey shading indicates the parts of the chronologies where the EPS falls below 0.85 . The dashed vertical line indicates the point before which there are less than three trees in the mean density chronology.

Fig. 4. Wavelet power spectra (Morlet wavelet) and global wavelet of (a-b) the mean density chronology, (c-d) the TRW chronology and (e-f) reconstructed JanT $T_{\max }$. Black contours indicate the $10 \%$ significance level, using a white-noise background spectrum. The hatched area is the cone of influence, indicating regions subject to edge effects. Wavelet power spectra were produced using the online interactive toolkit by Torrence and Compo (available:

707 http://paos.colorado.edu/research/wavelets/)

[1 column width]

Fig. 5. Correlations between the (a) mean density, (b) cell wall thicknes (CWT), and (c) ring width (TRW) chronologies and monthly temperature variables in the current and previous growing season. Black bars represent mean monthly maximum temperatures $\left(T_{\max }\right)$, medium grey bars represent mean monthly mean temperatures $\left(T_{\text {mean }}\right)$, and light grey bars represent mean monthly minimum temperatures $\left(T_{\min }\right)$. Temperature data are derived from gridded CRU TS3.22 data and area-averaged over $41-43^{\circ} \mathrm{S}, 145.5-147.5^{\circ} \mathrm{E}$. Dotted horizontal lines represent the $5 \%$ significance level. Blue shaded area indicates the current growing season. The series were not linearly detrended prior to correlation. temperatures (JanT $T_{\max }$ ) over the last century (1920-2010 C.E.). Reconstructed JanT $\mathrm{max}_{\text {ax }}$ is shown by 
the thin black line. Observed JanT $\max$ is shown by the thin grey line. Linear trends in the reconstructed (black; $0.004^{\circ} \mathrm{C}^{-1} ; \mathrm{p}=0.285$ ) and observed (grey; $0.023^{\circ} \mathrm{C} \mathrm{yr}^{-1} ; \mathrm{p}<0.0001$ ) Jan $\mathrm{T}_{\max }$ are represented by thick lines. The linear trend in the reconstructed Jan $T_{\max }$ for only the 1920-2004 C.E. period is shown by the dotted black line $\left(0.013^{\circ} \mathrm{C} \mathrm{yr}^{-1} ; \mathrm{p}=0.055\right)$. A mismatch between the observed and reconstructed JanT $T_{\max }$ in 2005-2007 C.E. is highlighted by blue shading.

\section{[1.5 column widths]}

Fig. 7. (a) Reconstruction of January $T_{\max }$ based on ring width (TRW) and mean density of Athrotaxis cupressoides (this study), (b) the Mt Read reconstruction of summer (Nov-Apr) $\mathrm{T}_{\text {mean }}$ based on TRW of Huon Pine (Lagarostrobos franklinii; from Cook et al. 2000; and (c) the wavelet coherence between the two reconstructions. Note: $y$-axes are not directly comparable between $(a)$ and (b). Thin black lines indicate reconstructed temperatures, thin blue line in (a) is the observed $\mathrm{JanT}_{\max }$, light grey band in (a) represents the prediction interval (calculated with the predict function in R; R Core Team, 2015). Thick black lines represent 50-yr Loess smoothing curves of reconstructed (black) and observed (blue) temperatures. The red extension of the reconstruction in (a) shows the Loess smoothing curve if the 2004-2010 period is excluded from the reconstruction. Horizontal dashed lines represent the $1530-2010$ mean of reconstructed (a) January $T_{\max }\left(19.2^{\circ} \mathrm{C}\right)$ from PLMC and (b) summer $\mathrm{T}_{\text {mean }}\left(15^{\circ} \mathrm{C}\right)$ from Mt Read. Blue horizontal bars and vertical shading indicate periods when both reconstructions show below average temperatures (Loess curve below the longterm mean). Orange horizontal bars and vertical shading indicate periods when both reconstructions show above average temperatures (Loess curve above the long-term mean). Black contours in (c) indicate the $5 \%$ significance level. The white shaded area in (c) is the cone of influence, indicating regions subject to edge effects.

[2 column widths]
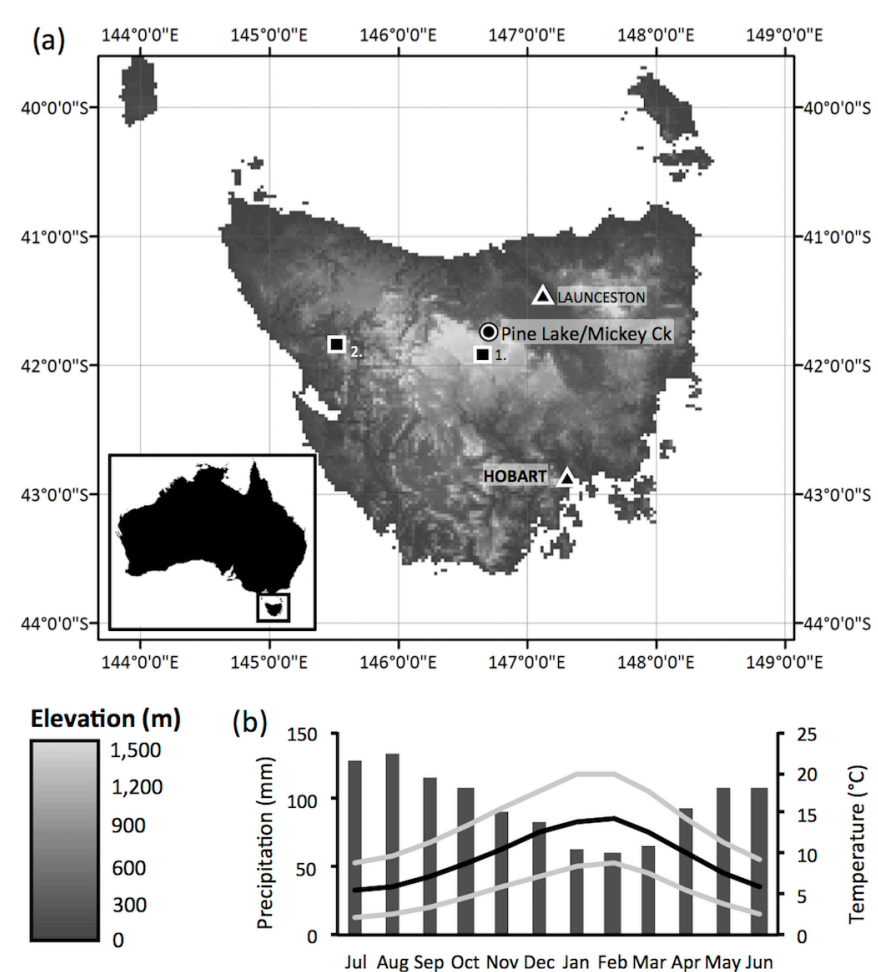

Fig. 1 

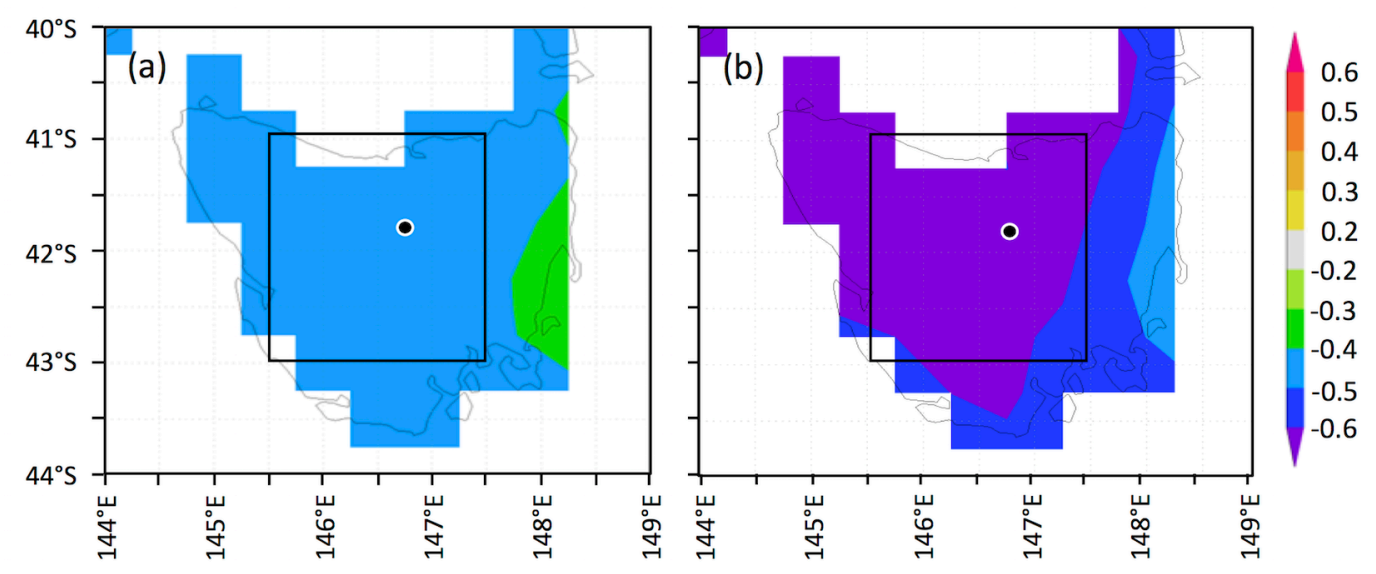

$747 \quad$ Fig. 2 

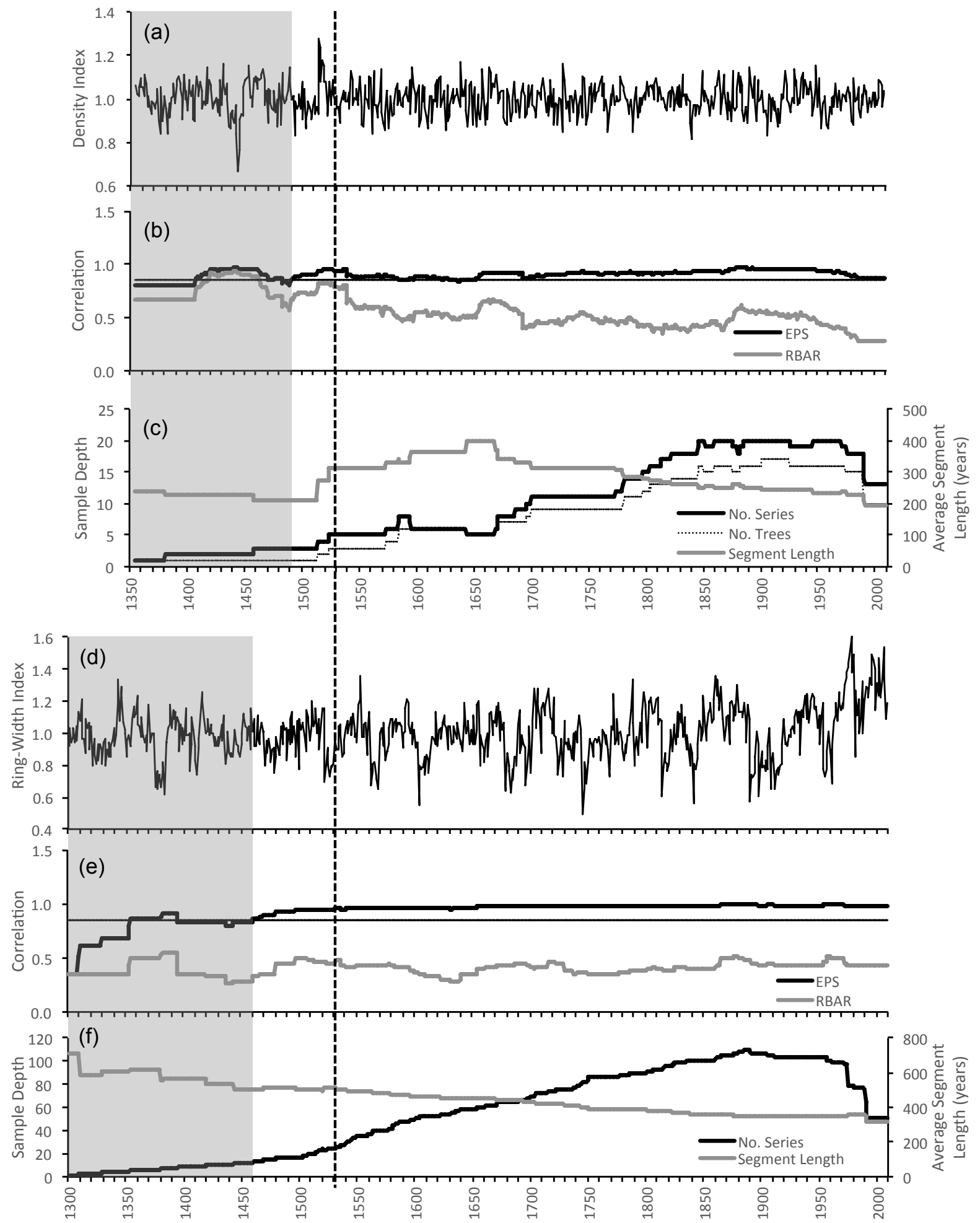

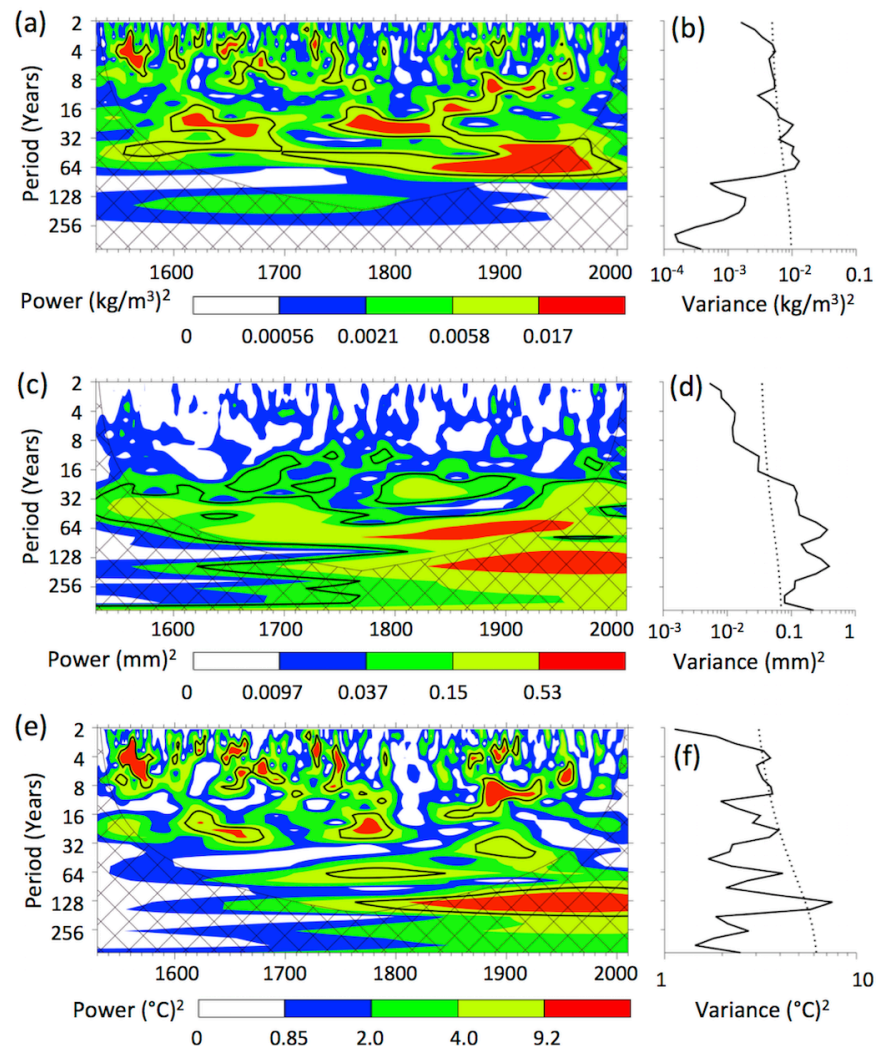

Fig. 4 

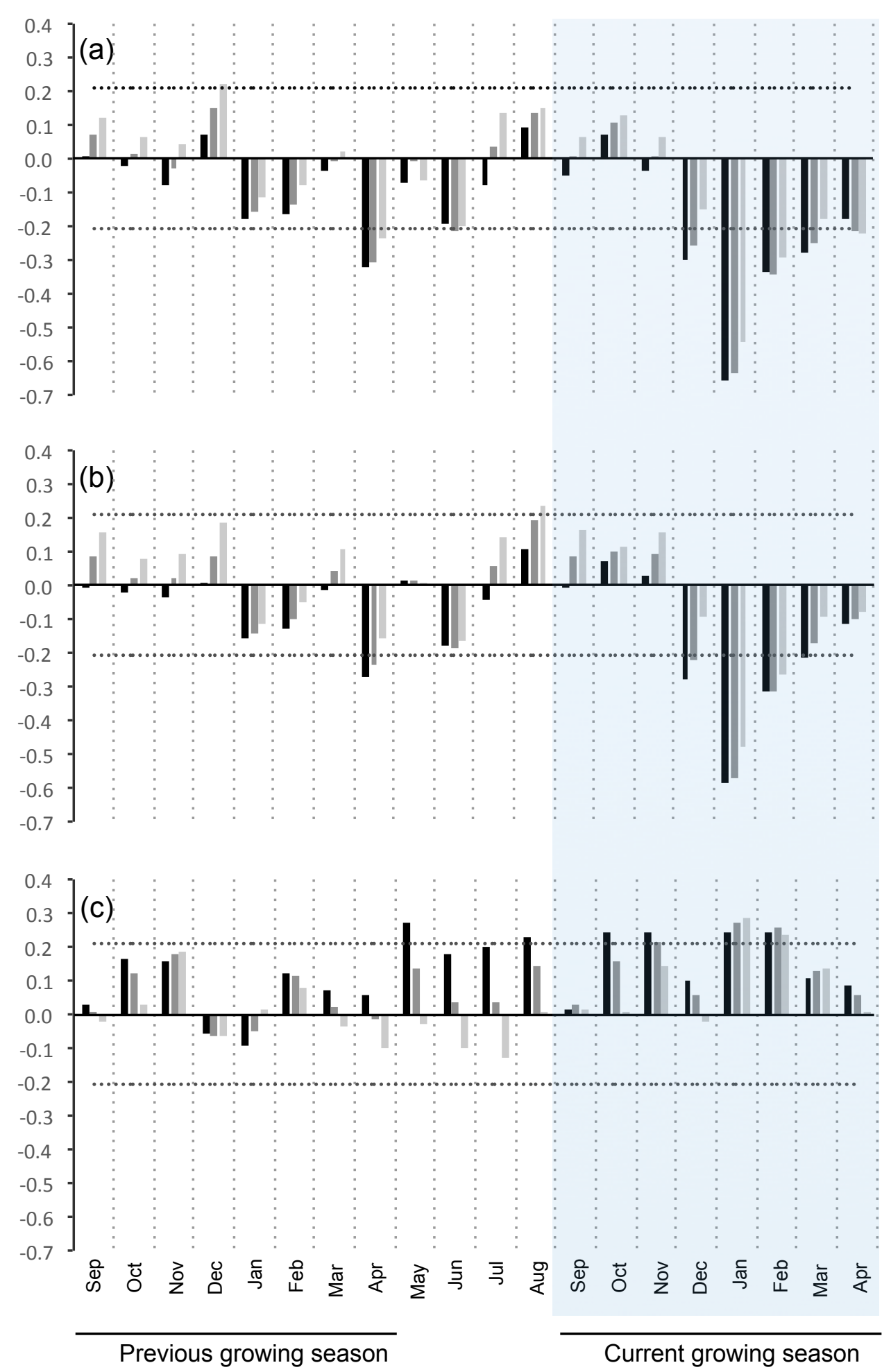

Fig. 5 


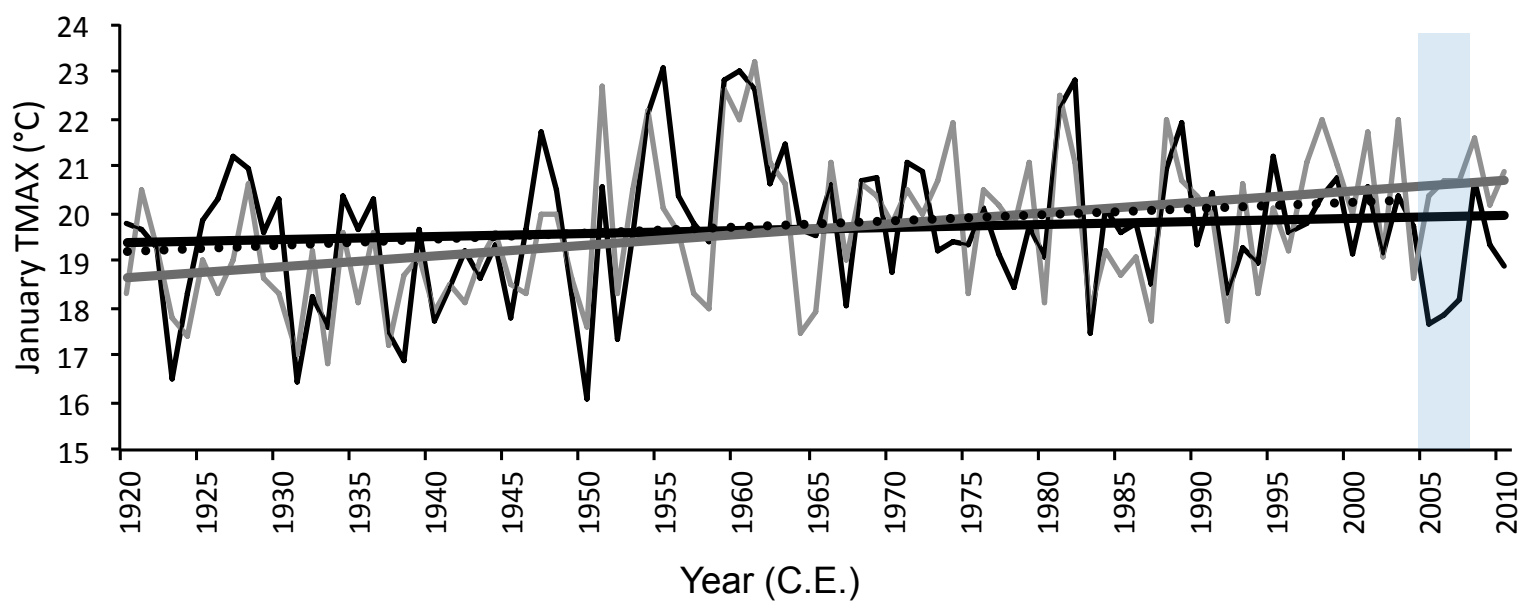

Fig. 6

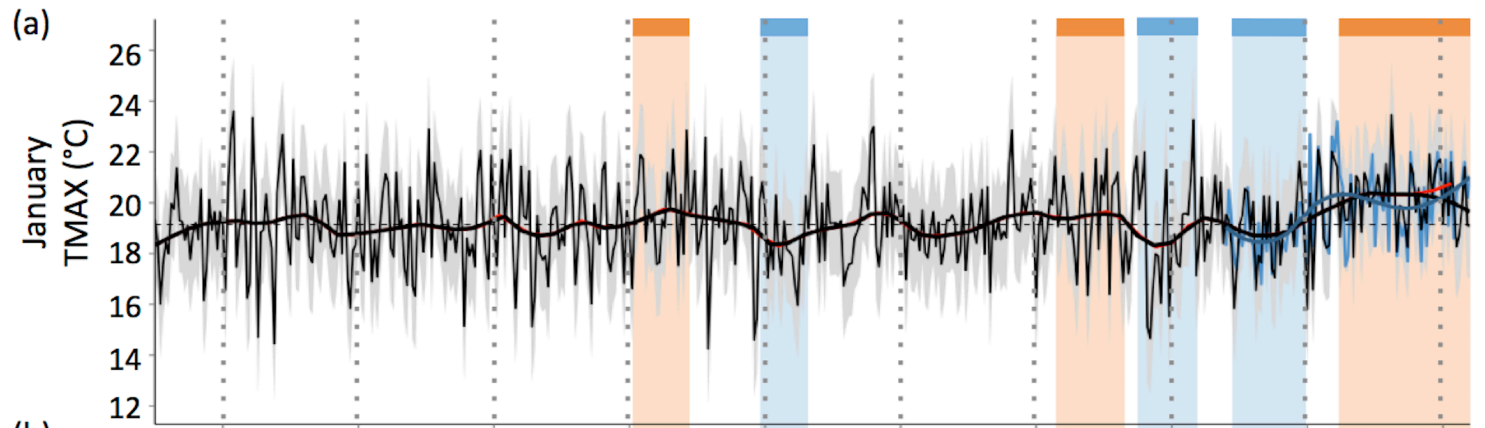

(b)
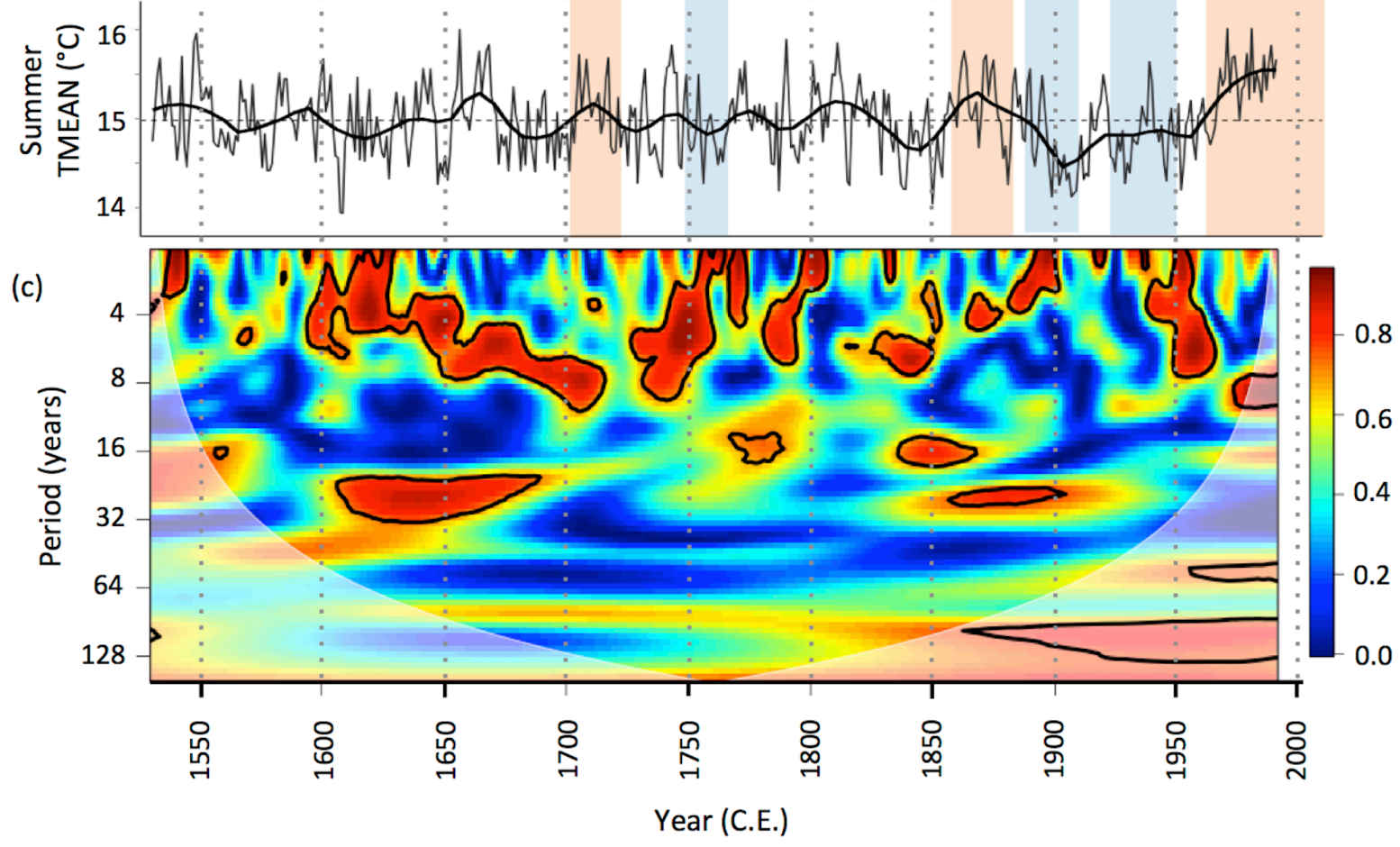

Fig. 7 